\title{
Stimulation of bacterial exoproteolytic activity by fish farming in coastal marine ponds: effect on dissolved protein cycling
}

\author{
Marie-José Garet, Hugues Reymond and Daniel Delmas \\ CREMA-L'Houmeau (CNRS-IFREMER), case 5, 17137 I'Houmeau, France. \\ E-mail :ddelmas@ifremer.fr
}

Received September 9, 1996; accepted April 11, 1997.

Garet M.J., H. Reymond, D. Delmas. Aquat. Living Resour., 1997, 10, $221-229$.

Abstract

The effect of fish farming on dissolved amino acid concentrations, bacterioplankton abundance and exoproteolytic activity was assessed in 3 experimental marine ponds. Different standing stocks of fish were introduced (semi-intensive pond: $250 \mathrm{~g} . \mathrm{m}^{-2}$; semi-extensive pond: $50 \mathrm{~g} \cdot \mathrm{m}^{-2}$; control pond: 0 ). Sea bass farming increased dissolved combined amino acid (DCAA) concentrations only in the semi-intensive pond. Bacterial standing stock was unaffected by fish food supply. However, bacterial exoproteolytic activity was strongly stimulated by aquaculture intensification; the average maximal rate of dissolved protein hydrolysis $\left(\mathrm{V}_{\mathrm{m}}\right)$ increased with intensity (control pond: $1500 \mathrm{nM} \cdot \mathrm{h}^{-1}$; semi-extensive pond: $2600 \mathrm{nM} \cdot \mathrm{h}^{-1}$; semi-intensive pond: $5100 \mathrm{nM} \cdot \mathrm{h}^{-1}$ ). DCAA fluxes through bacterial exoproteolytic activity ranged between 16 (semiextensive) and $11 \%$ (semi-intensive) of the daily nitrogen input by fish food. Bacterial exoproteolytic activity allowed a substantial part of the increased supply of dissolved amino nitrogen to be incorporated into bacterial biomass, then available for transfer to higher trophic levels within the ponds. It also significantly decreased dissolved organic nitrogen export from the ponds to the surrounding environment.

Keywords: Bacterial exoproteolytic activity, dissolved proteins, aquaculture, coastal marine ponds.

Stimulation de l'activité exoprotéolytique bactérienne par l'intensification de l'aquaculture en marais maritimes: effet sur le recyclage des protéines dissoutes.

Résumé

L'effet de l'intensification de l'aquaculture sur les teneurs en acides aminés dissous et sur l'activité exoprotéolytique bactérienne a été étudié dans 3 bassins expérimentaux où des densités croissantes de poissons ont été introduites (bassin 1/2 intensif : $250 \mathrm{~g} \cdot \mathrm{m}^{-2}$; bassin $1 / 2$ extensif : $50 \mathrm{~g} \cdot \mathrm{m}^{-2}$; bassin témoin : 0 ). L'intensification de l'élevage du bar conduit à une augmentation des teneurs en acides aminés dissous combinés uniquement pour l'élevage 1/2 intensif. La biomasse bactérienne n'est pas affectée par les apports d'aliment distribué aux poissons. Par contre, l'activité exoprotéolytique bactérienne est très fortement stimulée par l'élevage des bars ; ainsi, la vitesse maximale d'hydrolyse des protéines dissoutes $\left(\mathrm{V}_{\mathrm{m}}\right)$ par les bactéries augmente simultanément à l'intensification de l'aquaculture (bassin témoin: $1500 \mathrm{nM} \cdot \mathrm{h}^{-1}$; élevage $1 / 2$ extensif: 2600 nM.h ${ }^{-1}$; élevage $1 / 2$ intensif: $5100 \mathrm{nM} \cdot \mathrm{h}^{-1}$ ). Les flux de protéines dissoutes utilisées par les bactéries, grâce à l'activité exoprotéolytique, représentent en moyenne 16 (élevage $1 / 2$ extensif) et $11 \%$ (élevage $1 / 2$ intensif) de l'apport azoté journalier d'aliment. L'activité exoprotéolytique bactérienne constitue donc un processus important dans les bassins aquacoles qui permet le recyclage de l'azote aminé dissous en biomasse bactérienne, disponible pour les échelons trophiques supérieurs à l'intérieur des bassins, et conduit ainsi à une diminution des rejets de composés organiques dissous vers le milieu extérieur.

Mots-clés : Activité exoprotéolytique bactérienne, protéines dissoutes, intensification de l'aquaculture, marais maritimes. 


\section{INTRODUCTION}

In the aquatic environment, the bulk of dissolved organic matter occurs in the form of polymeric material and most of this remains unidentified (Munster and Chróst, 1990; Lee and Wakeham, 1992). Dissolved proteins constitute the largest identified pool of dissolved organic nitrogen (DON) (Gardner and Stephens, 1978; Sharp, 1983; Antia et al., 1991; Delmas et al., 1994), and can be important substrates for bacterial growth. They cannot be directly assimilated by bacteria, however, as only dissolved free amino acids (DFAA) and oligopeptides of up to five monomers can be taken up (Payne, 1980; Jorgensen, 1982; Hollibaugh and Azam, 1983; Furhman, 1987; Coffin, 1989). To permit microbial uptake and utilization of proteins, prior enzymatic depolymerization and cleavage into smaller subunits is thus required. Hence, bacterial exoproteolytic activity is a necessary and important process for bacterial growth and it potentially constitutes a rate-limiting step in the microbial utilization of dissolved polymeric amino nitrogen (Hollibaugh and Azam, 1983; Lancelot and Billen, 1984; Hoppe et al., 1988a; Hoppe, 1991; Chróst, 1991, 1992).

Along the French Atlantic Coast, shallow marine ponds cover several thousands of hectares of salt marshes. In these ponds, high concentrations of DON $(15-40 \mu \mathrm{M})$ and dissolved proteins $\simeq 3 \mu \mathrm{M}$ of constitutive amino acids) allow high bacterial biomasses to develop (Robert et al., 1982; Frikha, 1989; Delmas et al., 1992, 1994). Many of these ponds are used for aquaculture (Manaud et al., 1993); to increase the yield, food for animals or fertilizers, or both, are added to stimulate natural production (Moriarty and Pullin, 1987; Hussenot, 1992; Manaud et al., 1993). Stimulation of the production in aquaculture ponds leads to significant increases in the standing stock of dissolved organic nitrogen, which can in turn stimulate bacterial activity (Legrand, 1993; Delmas et al., 1994). The bacterial community which cycles these nutrients thus represents a key link in the food chain in aquaculture ponds (MacLean et al, 1994; Allan et al., 1995).

More intensive aquaculture may increase waste production which can affect animal production itself, as well as the quality of the surrounding environment (Beveridge et al., 1991; Briggs and Funge-Smith, 1994; Krom et al., 1995). The amount of dissolved inorganic (e.g. ammonia) or particulate organic matter produced during aquaculture has frequently been investigated (Krom and Neory, 1989; Briggs and Funge-Smith, 1994), but the fate of dissolved organic matter and its action on the bacterial community is poorly known.

The aim of this study was to evaluate how fish farming intensity affects dissolved organic matter concentrations (mainly dissolved combined and free amino acids, DCAA and DFAA) and to investigate how bacterial exoproteolytic activity responds to such enrichment.

\section{METHODS}

\section{Fish pond management}

Three similar experimental fish ponds were studied during 1993 in Noirmoutier Island at the Aqualive Station (on the Atlantic coast of France). They were $500 \mathrm{~m}^{2}$ in area and $1 \mathrm{~m}$ in depth. A main channel carried decanted sea water from the reserve, then two side channels supplied water to the ponds: the control pond was fed by channel 1 and the aquaculture ponds were fed by channel 2 . The ponds were emptied and left exposed to the air during winter. They were refilled with decanted sea water on 26 April. One-year-old Dicentrarchus labrax (mean weight: $27.5 \mathrm{~g}$ ) were introduced on 6 May into the semi-intensive pond at a stocking biomass of $248 \mathrm{~g} \cdot \mathrm{m}^{-2}$, and into the semiextensive pond at $50 \mathrm{~g} \cdot \mathrm{m}^{-2}$; biomasses had reached, respectively, 710 and $140 \mathrm{~g} \cdot \mathrm{m}^{-2}$ at the end of the experiment on 11 October; whereas no fish were added in the control pond. Daily water changes were carried out at the same time each morning; from 26 April to 18 July water renewals were $20 \%$ per day for each pond and $30 \%$ per day after that. The amount of food supplied was a function of the fish biomass, individual fish weight and water temperature (Fig. 1); food was introduced by scattering two or three times daily.

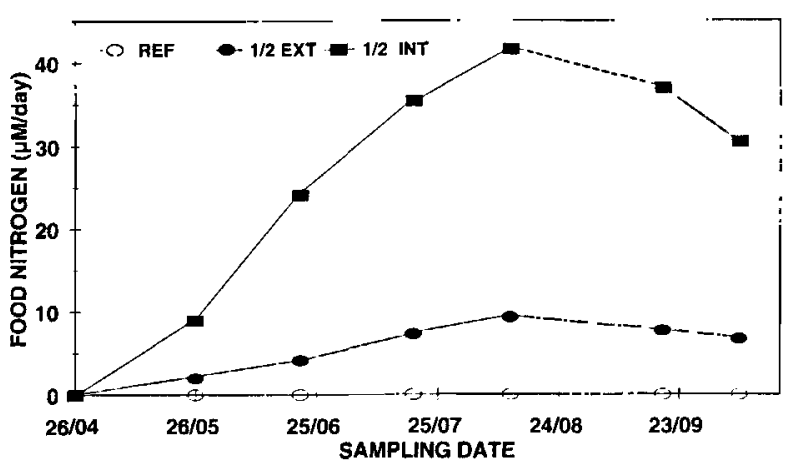

Figure 1. - Daily average of the nitrogen supply by fish food in experimental ponds. REF: control pond; $1 / 2 \mathrm{EXT}$ : scmi-extensive pond; 1/2 INT: semi-intensive pond.

\section{Sample collection and treatment}

Water temperature was measured daily, two hours after sunrise. For dissolved amino compounds measurements, water was sampled every 10 days from April to October 1993, between $11^{\mathrm{AM}}$ and $12^{\mathrm{PM}}$. Bacterial numbers and exoproteolytic activity were determined monthly. To estimate the input of dissolved 
amino compounds by the feed waters, the feeding channels were sampled during water exchange. For the measurement of dissolved combined and dissolved free amino acids (DCAA, DFAA), bacterial abundance and exoproteolytic activity in ponds, samples were taken just before the water was changed.

Within minutes of collection, samples for the determination of DCAA and DFAA were filtered by gravity through precombusted glass fibre filters $(\mathrm{GF} / \mathrm{F})$ and immediately frozen. For bacterial counts, a 20-ml sample was preserved in a clean scintillation vial and fixed with borate-buffered formalin ( $2 \%$ final concentration). Bacterial exoproteolytic activity was assayed by measuring the hydrolysis of the non-fluorescent protein model substrate (L-leucine-4-methyl-7-coumarinylamide, LLMCA), which yields the fluorescent, 4-methyl-7-coumarinylamine (Hoppe, 1983, 1993; Chróst et al., 1989). Samples were always processed within minutes of collection. To study the kinetics of the exoproteolytic activity, $50 \mu \mathrm{l}$ of $0.31,0.62,1.25$, $2.5,5,10,20$ or $40 \mathrm{mM}$ LLMCA were added to $2 \mathrm{ml}$ of pond water (one sample and one sodium dodecyl sulfate inhibited control for each LLMCA concentration) yielding final LLMCA concentration of 7.8, 15.6, 31.2, $62.5,125,250,500$, and $1000 \mu \mathrm{M}$. After one hour of incubation at in situ temperature, samples were inhibited by sodium dodecyl sulfate at $1 \%$ final concentration (Delmas and Garet, 1995) and frozen until analysis.

\section{Analytical methods}

Measurements of dissolved free primary amines were carried out by flow injection analysis with o-phthaldialdehyde using glycine as the standard (Delmas et al., 1990). Total dissolved primary amines were measured as primary amines after acid hydrolysis $(\mathrm{HCl}$ $5.8 \mathrm{~N}, 20$ hours at $105^{\circ} \mathrm{C}$ ) and neutralization. DFAA were estimated from dissolved primary amine measurements by correcting the values for ammonia interference with o-phthaldialdehyde (Delmas et al., 1990), concentrations of DCAA were calculated as the difference between total dissolved primary amines and dissolved primary amines. Bacteria were enumerated by direct counting after staining with acridine orange (Hobbie et al., 1977). Release of the fluorescent 4-methyl-7-coumarinylamine by bacterial exoproteolytic activity was measured by flow injection analysis using a Kontron high performance liquid chromatograph fitted with a Kontron SFM 25 spectrofluorometer (Delmas et al., 1994). Data were recorded by a Shimadzu CR1B integrator. For Flow injection analysis, teflon tubing $(1.5 \mathrm{~m}$ long, $0.3 \mathrm{~mm}$ internal diameter) was used to connect the injection valve with the detector. A buffered solution $(0.1 \mathrm{M}$ boric acid $\mathrm{pH} 10)$ was delivered by the pump at a flow rate of $1 \mathrm{ml} \cdot \mathrm{min}^{-1}$ and a full loop of sample $(20 \mu \mathrm{l})$ was directly injected. Fluorescence was measured using excitation at $380 \mathrm{~nm}$ and emission at $440 \mathrm{~nm}$. A 4- methyl-7-coumarinylamine solution was used as the standard.

The kinetics parameters, $\mathrm{V}_{\mathrm{m}}$ and $\mathrm{K}_{\mathrm{m}}$, were calculated from direct plots of reaction velocity versus substrate concentration, by non-linear least squares regression using the computer program Kinetics (Brooks, 1992).

One-way analysis of variance were used to check the effect of aquaculture intensification on the measured variables. Unless otherwise indicated, values in the text are mean \pm 1 standard deviation.

\section{RESULTS}

The pond temperatures showed typical seasonal variation increasing regularly from $16^{\circ} \mathrm{C}$ (April) up to maximum value in August $\left(20^{\circ} \mathrm{C}\right)$, then decreasing in the early autumn. Temperature differences between ponds were always $<0.2^{\circ} \mathrm{C}$.

\section{Dissolved amino compounds}

In feed waters, DFAA concentrations did not show any seasonal trend, but some large variations can be observed (Fig. 2). Concentrations of DFAA were typically in the range $0.20-1.60 \mu \mathrm{M}$ (channel 1: $0.52 \pm$ $0.25 \mu \mathrm{M}, \mathrm{n}=18$; channel 2: $0.53 \pm 0.36 \mu \mathrm{M}, \mathrm{n}=17$ ).
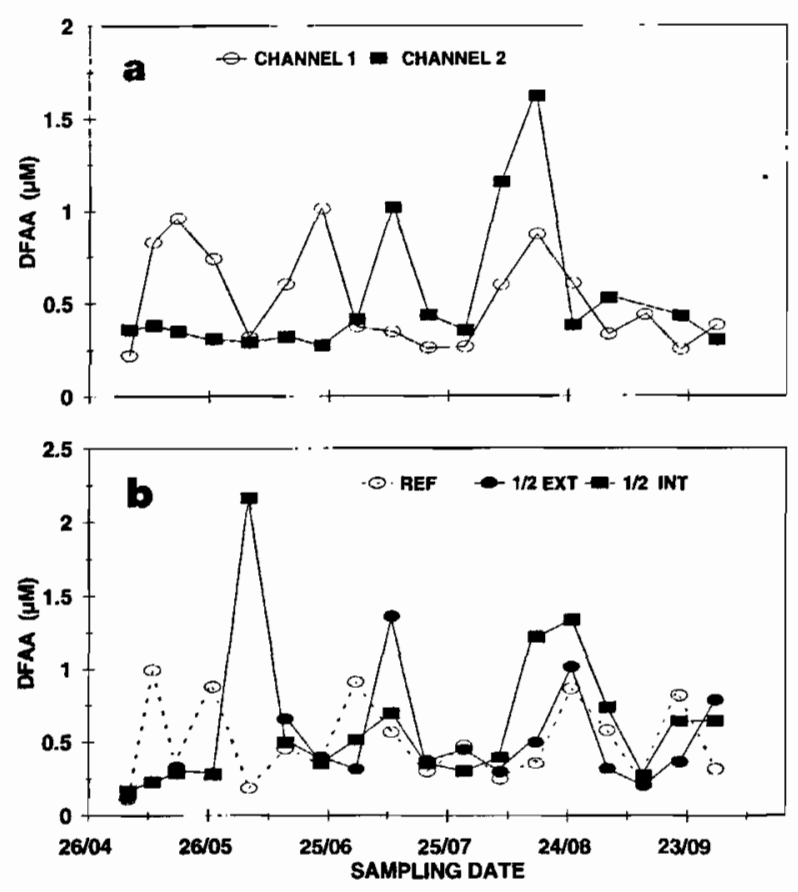

Figure 2. - Dissolved free amino acids (DFAA) concentrations in feed waters (a) and in experimental ponds (b) during the survey. Channel 1; feed water for the control pond; Channel 2: feed water for the semiextensive and the semi-intensive ponds; REF: control pond; 1/2 EXT : semi-extensive pond; $1 / 2$ INT: semi-intensive pond. 
In the pond waters, erratic changes in DFAA occurred in both ponds. Overall DFAA concentrations in these ponds were in the same range as those in the feed waters (range: $0.10-2.00 \mu \mathrm{M}$; control pond: $0.50 \pm$ $0.25 \mu \mathrm{M}, \mathrm{n}=18$; semi-extensive pond: $0.49 \pm 0.31 \mu \mathrm{M}$, $\mathrm{n}=16$; semi-intensive pond: $0.62 \pm 0.49 \mu \mathrm{M}, \mathrm{n}=18$ ).

In the feed waters, DCAA concentrations were typically in the range of $2-3 \mu \mathrm{M}$ (channel 1: $2.35 \pm$ $0.69 \mu \mathrm{M}, \mathrm{n}=17$; channel $2: 2.38 \pm 0.67 \mu \mathrm{M}, \mathrm{n}=18$ ); so the DCAA input was essentially the same in both feed channels (Fig. 3). DCAA concentrations in pond waters were significantly affected by aquaculture intensification (Table 1). DCAA showed a similar temporal trend in both the control and semi-extensive pond (Fig. 3). In the semi-intensive pond, DCAA concentrations were generally higher than in the two other ponds (between 1 to $2 \mu \mathrm{M}$ more) and showed large temporal fluctuations.
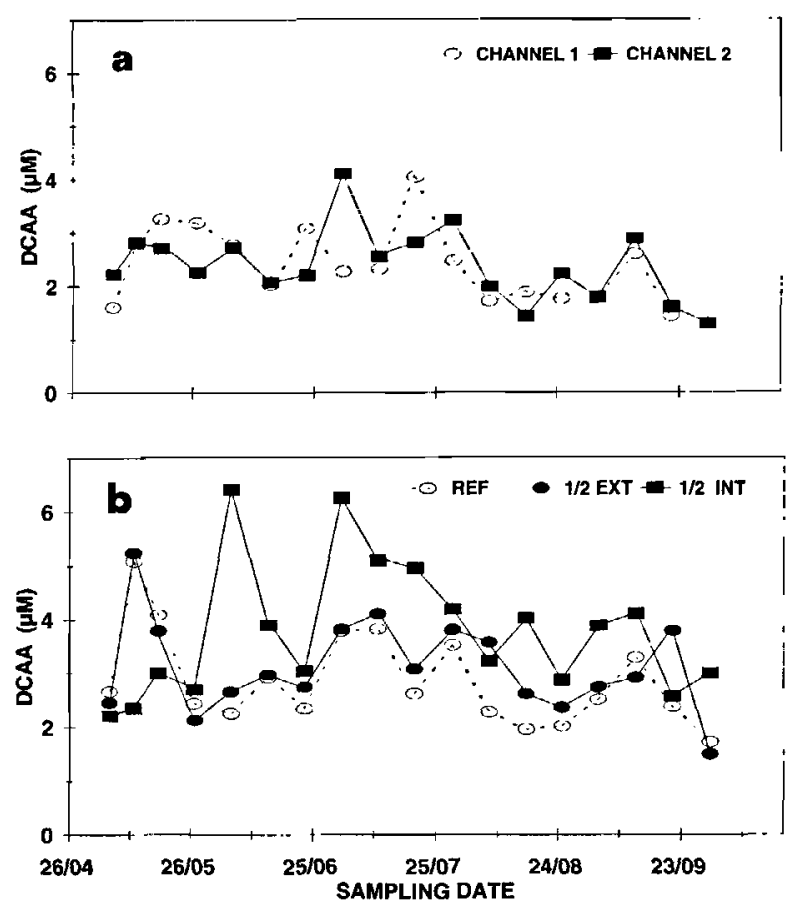

Figure 3. - Dissolved combined amino acids (DCAA) concentrations in feed waters (a) and in experimental ponds (b) during the survey. Channel 1: feed water for the control pond; Channel 2: feed water for the semi-extensive and the semi-intensive ponds; REF: control pond; 1/2 EXT : semi-extensive pond; 1/2 INT: semi-intensive pond.

\section{Bacterial abundance and activity}

In pond waters, bacterial abundance was in the range 1.1 to $9.0 \times 10^{6}$ cells. ml ${ }^{-1}$ (Fig. $4 a$ ). In each pond, during the first part of the experiment (until mid July), bacterial biomass was twice as high (control pond: $3.89 \pm 0.73 \times 10^{6}$ cells. $^{-1}$; semi-extensive pond: 4.29 $\pm 1.06 \times 10^{6}$ cells. $\mathrm{m}^{-1}$; semi-intensive pond: $5.27 \pm$
Table 1. - Effect of aquaculture intensification on the measured variables, results from one-way analysis of variance (NS: no significant; *: significant at $5 \%$ level).

\begin{tabular}{lcccc}
\hline & $\begin{array}{c}\text { Degrec } \\
\text { of freedom }\end{array}$ & $\begin{array}{c}\text { Sum } \\
\text { of Square }\end{array}$ & F-ratio & Probability \\
\hline DCAA & & & & \\
in feed water & & & & \\
Between groups & 2 & 0.01 & 0.017 & $0.983 \mathrm{NS}$ \\
Within groups & 48 & 21.6 & & \\
Total & 50 & 21.6 & & \\
DCAA & & & & \\
in pond water & & & & \\
Between groups & 2 & 7.7 & 3.710 & $0.03 *$ \\
Within groups & 51 & 53.0 & & \\
Total & 53 & 60.7 & & \\
DCAA enrich- & & & & \\
ment in pond & & & & \\
Between groups & 2 & 6.3 & 3.455 & $0.04 *$ \\
Within groups & 48 & 43.8 & & \\
Total & 50 & 50.1 & & \\
Bacteria number & & & & \\
Between groups & 2 & 7.5 & 1.339 & $0.29 \mathrm{NS}$ \\
Within groups & 18 & 50.3 & & \\
Total & 20 & 57.7 & & \\
Exoproteolytic & & & & \\
activity (V & & & & \\
Between groups & 2 & $4.8 \times 10^{7}$ & 4.034 & $0.04 *$ \\
Within groups & 18 & $1.1 \times 10^{8}$ & & \\
Total & 20 & $1.6 \times 10^{8}$ & & \\
\hline
\end{tabular}

$2.51 \times 10^{6}$ cells.ml-1) as that during the latter part of the experiment (control pond: $1.54 \pm 0.37 \times 10^{6}$ cells. $\mathrm{ml}^{-1}$; semi-extensive pond: $2.34 \pm 0.11 \times 10^{6}$ cells.ml-1; semi-intensive pond: $3.08 \pm 0.86 \times 10^{6}$ cells. $\mathrm{ml}^{-1}$ ). Bacterial abundances were generally lower in the control pond; however, no significant differences in bacterial counts could be found according to the level of aquaculture intensification (Table 1).

Bacterial exoproteolytic activity $\left(V_{m}\right)$ followed a strong seasonal pattern, values increasing from April to August then decreasing to the initial values during the early fall (Fig. 4b). Significant differences in exoproteolytic activity between ponds were found (Table 1), particularly during summer. Activities in the semi-intensive pond were 3 times higher (mean: 5102 nM.h-1, range: $819-11491$ nM.h $^{-1}$ ) than in the control pond (mean: 1467 nM.h. ${ }^{-1}$, range: 326$\left.2330 \mathrm{nM}^{-1}\right)$ and $\approx$ twice as high as in the semiextensive pond (mean: 2629 nM.h ${ }^{-1}$, range: 389 $5200 \mathrm{nM} \cdot \mathrm{h}^{-1}$ ).

\section{DISCUSSION}

\section{Effect of aquaculture on dissolved amino compounds}

In the ponds under study, DFAA concentrations are in the typical range of values reported both for continental lakes, estuaries and for Atlantic coastal marine ponds (range: 0.2 to $1.5 \mu \mathrm{M}$; Jorgensen, 1982; Coffin, 

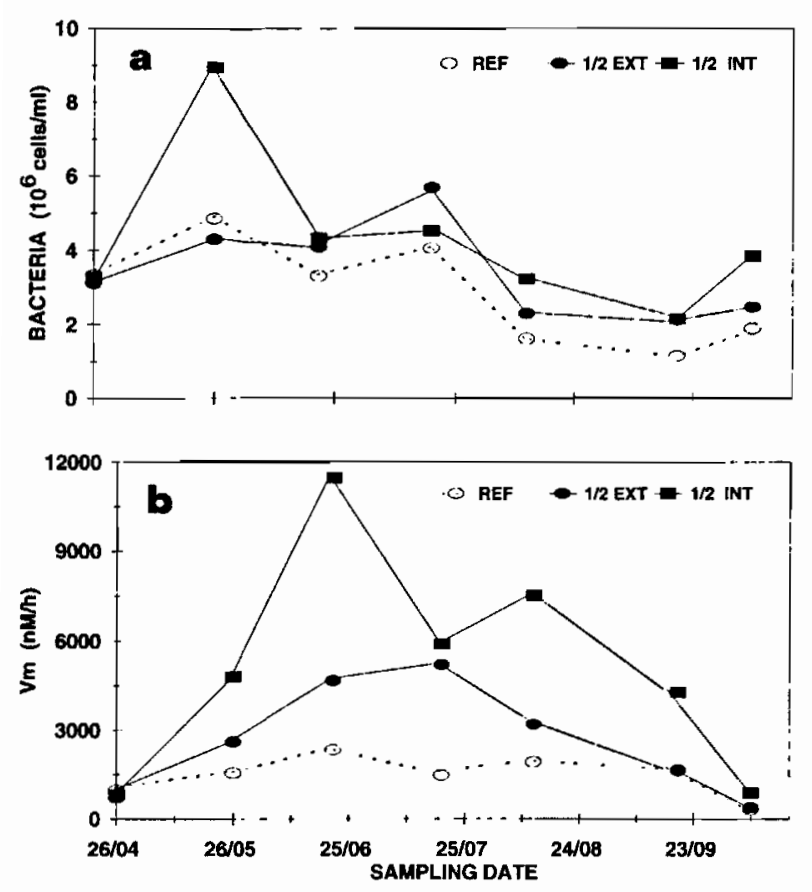

Figure 4. - Seasonal evolution of bacteria number (a), and maximal rate $\left(\mathrm{V}_{\mathrm{m}}\right)$ of exoproteolytic activity (b), in fishponds. REF: control pond; 1/2 EXT : semi-extensive pond; 1/2 INT: semi-intensive pond.

1989; Delmas et al., 1990, 1994). However, these values are higher than those generally reported for marine waters (range 0.05 to $0.3 \mu \mathrm{M}$; Mopper and Lindroth, 1982). In spite of the additions of fish food, the absence of DFAA enrichment in both the semi-extensive and semi-intensive ponds can be explained by the rapid cycling of these compounds (turnover time $<10$ h; Jorgensen, 1982; Coffin, 1989; Fuhrman. 1987).

DCAA concentrations in the aquaculture ponds are in the range of values typically measured in estuarine waters (range: 0.1-10 $\mu \mathrm{M}$; Coffin, 1989; Keil and Kirchman, 1991). An increase in DCAA concentrations occurs during the residence of the water in the ponds (control pond: $+28 \% \pm 35$; semi-extensive pond: $+37 \% \pm 39$; semi-intensive pond: $+65 \% \pm 52$; $\mathrm{n}=18$ ); and this enrichment is significantly affected by aquaculture intensification. In order to estimate the effect of aquaculture intensity on DCAA standing stock, it is instructive to compare the concentrations in the experimental ponds with those in the control pond (Fig. 5). For the semi-extensive pond the enrichment is low $(0.25 \pm 0.48 \mu \mathrm{M}, \mathrm{n}=18)$; however, a larger increase in DCAA occurs in the semi-intensive pond $(0.90 \pm 1.43 \mu \mathrm{M}, \mathrm{n}=18)$. The low fish treatment has only a slight effect on DCAA concentrations and enrichment. This could be explained by the low input of feed nitrogen (mean: $5.2 \mu \mathrm{M}$.day ${ }^{-1}$ ) compared to the total dissolved nitrogen found either in feed waters or in the control pond $(\approx 12 \mu \mathrm{M}$ and $9.2 \mu \mathrm{M}$ respectively,

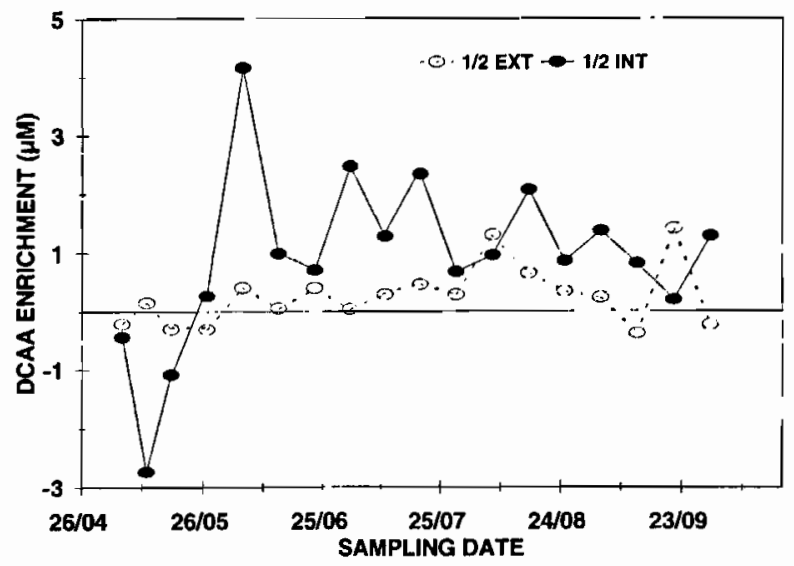

Figure 5. - Enrichment by dissolved combined amino acids (DCAA) in semi-extensive (1/2 EXT) and in semi-intensive (1/2 INT) fish ponds compared with the control pond. Enrichment is calculated as the difference in DCAA concentrations between experimental and control ponds.

Reymond unpublishd results). In the same way, the largest DCAA concentration in the semi-intensive pond results probably from the highest nitrogen input by fish food (mean: $26 \mu \mathrm{M}$.day ${ }^{-1}$ ).

DCAA concentrations and increases in the experimental ponds are not directly linked to the nitrogen input by food. This result is not surprising as the sea bass is known to ingest food very rapidly and efficiently; thus only a small amount of non-ingested food is able to enrich directly the DCAA standing stock. However, fish can indirectly increase the DCAA pool through their excretions (faeces dissolution). For instance, the sea bass excreted most of the nitrogen supplied by food as dissolved ammonia and urea (up to $80 \%$, Jobling, 1993), these nutrients support large phytoplankton blooms in aquaculture ponds (Krom and Neori, 1989; Krom et al., 1989). In the ponds under study, the mean chlorophyll concentrations were: $1.6 \mu \mathrm{g} . \mathrm{l}^{-1}$ in the control pond, $3.7 \mu \mathrm{g} . \mathrm{l}^{-1}$ in the semiextensive pond and $11 \mu \mathrm{g} . \mathrm{I}^{-1}$ in the semi-intensive pond (H. Reymond, unpublished results). Phytoplankton blooms, resulting from fish excretion, might thus have been an important source of DCAA through cell lysis and zooplankton sloppy feeding (Lampert, 1978; Jumars et al., 1989).

\section{Bacterial response to aquaculture}

Bacterial abundance seemed unaffected by the food supplies in ponds; apart from a significant decrease in the cell numbers in all the ponds from July 18 th, when water renewal was increased from 20 to $30 \%$ by day. The seasonal increase of exoproteolytic activity (control pond: $\times 2$, semi-extensive pond: $\times 5-7$, semi-intensive pond: $\times$ 9-14) largely overbalance a single temperature effect $\left(+6^{\circ} \mathrm{C}\right)$ on enzyme activity $\left(Q_{10}\right.$ : 1.9-2.4, Hoppe, 1983; Rosso and Azam, 1987; Delmas et al., 1994). In the control pond maximal rates of pro- 
Table 2. - Bacterial exoprotenlytic activities in marine and freshwater environments ( $\mathrm{V}_{\mathrm{m}}$ : maximal velocity of the cxoproteolytic activity; $\mathrm{V}_{s}:$ specific exoproteolytic activity: $t_{n}$ : turnover time of dissolved proteins estimated from the kinetic parameters of the exoproteolytic activity).

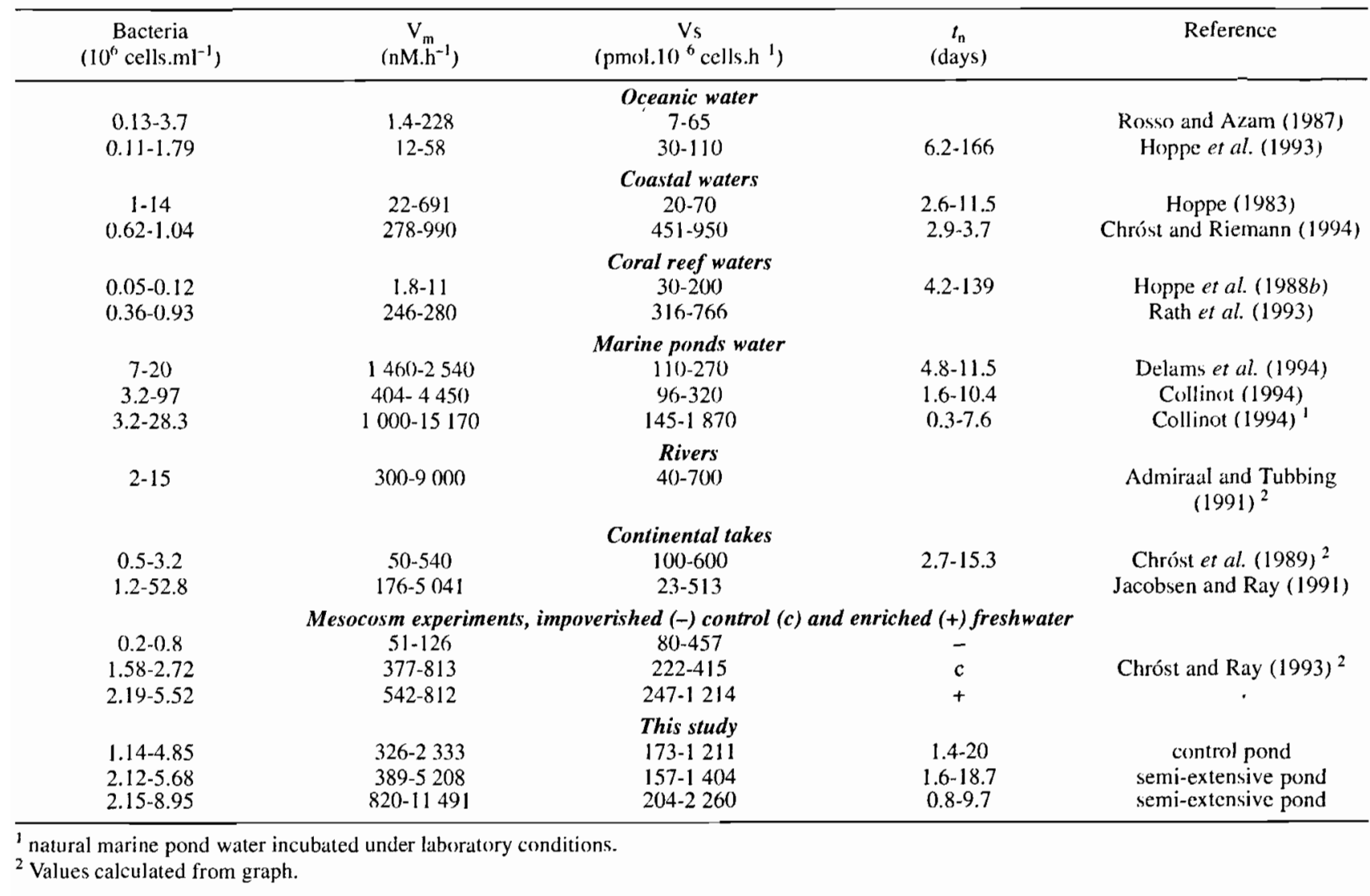

tein hydrolysis were in the range of values reported for Atlantic coastal marine ponds (Delmas et al., 1994); whereas values measured in the semi-extensive pond were in the higher part of the range found in rivers and eutrophic lakes (Admiraal and Tubbing, 1991; Jacobsen and Ray, 1991). In the semi-intensive pond, maximal rates exceed all the published values found in any marine or fresh water environment (Table 2). Then, unlike their biomass, the exoproteolytic activity of the bacteria showed a strong response to aquaculture intensification, increasing with the amount of food supply. The level of stimulation of the bacterial exoproteolytic activity by aquaculture reflects the enrichment in DCAA observed in ponds; however, bacterial protein utilization is partly controlled by DFAA availability (Keil and Kirchman, 1993). Thus, the increase of exoproteolytic activity with aquaculture intensification, mainly in the semi-intensive pond, may also indicate a shift in the balance between the contribution of free and polymeric amino compounds to bacterial production. Such an adjustment in the bacterial utilization of monomeric versus polymeric dissolved compounds was also observed in nutrient-enriched mesocosm (Chróst and Rai, 1993).

Cell specific enzyme activities ranged between 173-1 211 pmol. $10^{-6}$ cells. $h^{-1}($ mean $=647, n=7)$ in the control pond and 204-2 260 pmol.10 $10^{-6}$ cells. $\mathrm{h}^{-1}$ (mean $=1326, \mathrm{n}=7$ ) in the semi-intensive pond. These values are higher than generally found for bacteria from both marine, coastal and freshwater (Table 2). Such high values have been approached only in mesocosm experiments with nutrient enriched freshwater (Chróst and Ray, 1993). Since cell specific enzyme activity correlated with DCAA concentration $(\mathrm{r}=0.546, \mathrm{n}=18, p<5 \%)$ and as bacterial exoproteolytic enzymes are induced by their substrate (Chróst, 1991). This, firstly, suggests that the high specific activities found in fishponds reflect the ability of the bacterial community to hydrolyse dissolved proteins originating from aquacultural enrichment and, secondly, confirms the increasing importance of the pathway for cycling dissolved amino compounds as the aquaculture intensity rises.

The turnover times $\left(t_{n}\right.$, Table 3$)$ of dissolved proteins (DCAA) were estimated from the parameters of the proteolytic kinetics (Wright and Hobbie, 1966; Hoppe et $a l,, 1988 a$ ). In the control and the semi-extensive ponds, similar $t_{\mathrm{n}}$ values were found (respectively, mean $=6.5$ days, range: 1.4 to 20 days, mean $=6.5$ days, range: 1.6 to 18.8 days); in contrast, $t_{\mathrm{n}}$ values reduced by half in the semi-intensive fishpond (mean: 2.8 days, range: 0.8 to 9.7 days). These turnover times agree 
Table 3. - Estimates of the generation time ( $\mathrm{g}$ ) of bacteria from dissolved protein utilization in the experimental ponds (REF: control pond, $1 / 2$ EXT: semi-extensive pond; 1/2 INT: semi-intensive pond).

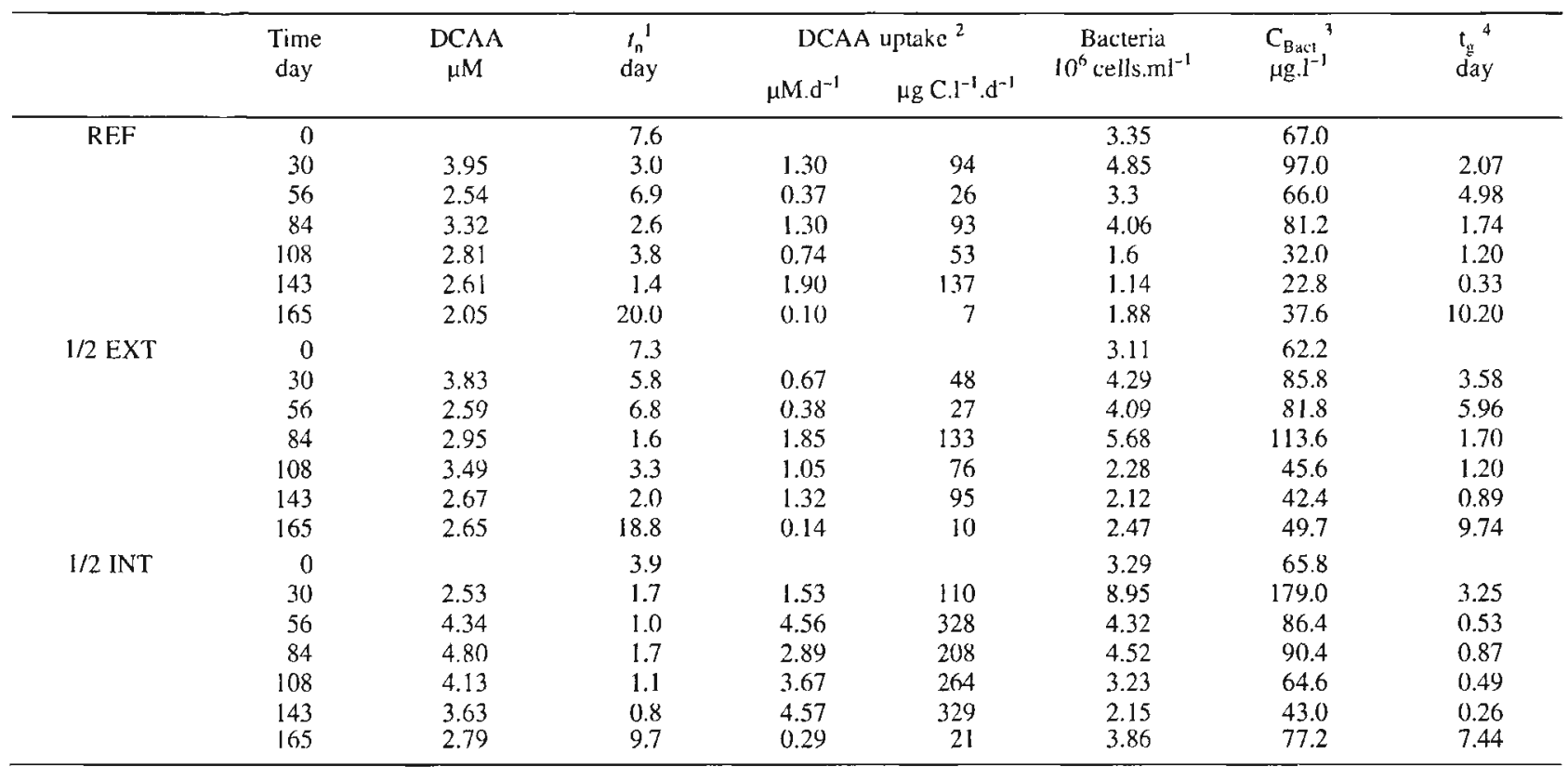

${ }^{1}$ Tumover time $\left(t_{\mathrm{n}}\right)$ of dissolved proteins estimated from kinetic parameters of the exoproteolytic activity $\left(t_{\mathrm{n}}=\mathrm{K}_{\mathrm{m}} / \mathrm{V}_{\mathrm{m}}\right)$.

${ }^{2}$ DCAA uptake in $\left(\mu \mathrm{M} . \mathrm{d}^{-1}\right)=\mathrm{DCAA} / t_{\mathrm{n}}$

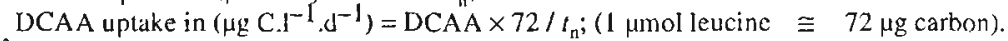

${ }^{3}$ Bacterial Carbon $\left(\mathrm{C}_{\mathrm{Bact}}\right): 20 \mathrm{fg}$ carbon per cell.

${ }^{4}$ Generation time $\left(t_{\mathrm{g}}\right)=\mathrm{C}_{\mathrm{Bat}} /$ (DCAA uptake $\left.\times 0.5\right) ;(0.5: 50 \%$ efficiency).

with values determinated with peptide analogue (Table 2), with radiolabelled dissolved proteins (Hollibaugh and Azam, 1983; Coffin, 1989) and from real DCAA consumption (Rosenstock and Simon, 1993). The fluxes of DCAA used by bacteria ([DCAA]/ $t_{\mathrm{n}}$, Table 3) are on average in the same range for both the control $\left(0.95 \mu \mathrm{M} . \mathrm{d}^{-\mathrm{I}}\right)$ and the semi-extensive pond $\left(0.90 \mu \mathrm{M} . \mathrm{d}^{-1}\right)$ but they are three times higher in the semi-intensive pond $\left(\right.$ mean $\left.=2.92 \mu \mathrm{M} \cdot \mathrm{d}^{-1}\right)$. In the semi-intensive pond, the amount of DCAA used by bacteria equals the DCAA standing stock remaining before water exchange (Table 3 ), hence, bacterial activity significantly decreased the release of dissolved organic matter from the pond into the surrounding environment. In terms of nitrogen, bacteria utilized dissolved proteins on average at $16 \%$ (range: $2-32 \%$ ) and $11 \%$ (range: $1-19 \%$ ) of the daily nitrogen introduced in fishfood in the semi-extensive and in the semi-intensive fishponds respectively.

Amino acids freed by bacterial exoproteolytic activity are taken up by bacteria (Hollibaugh and Azam, 1983; Rosenstock and Simon, 1993), and contribute significantly to bacterial secondary production (Coffin, 1989; Jorgensen et al., 1993; Keil and Kirchman, 1993; Middelboe et al., 1995). If we assume that DCAA freed by exoproteolytic activity are converted into bacterial biomass with $50 \%$ efficiency, we can estimate a minimum bacterial production based only on dissolved protein uptake. Average bacterial genera- tion times deduced from these estimates were similar for the control and the semi-extensive ponds (respectively $3.42 \pm 3.67$ days, and $3.85 \pm 3.45$ days). Lower generation times were estimated for the semi-intensive pond (average: $2.14 \pm 2.82$ days), with four out of the six estimated generation times below 1 day. Such decreases in the generation time of bacteria have been previously observed in fertilized aquaculture ponds (Moriarty, 1986). In pond waters, we did not observe any increase in bacterial biomass in spite of the short estimated doubling time. Moreover, the generation time of bacteria was lower than the turnover time of water in the ponds ( 5 days until 18 July and 3 days after). Thus the water exchange and the export of bacteria cannot explain the stability of the bacterioplankton standing stock, mainly in the semi-intensive pond. Therefore, we can suspect that in these ponds, as in other eutrophic environments (Frikha and Linley, 1988/1989; Sanders et al., 1992), bacterial biomass is essentially regulated by grazing processes and then transferred to the trophic chain.

Bacterial exoproteolytic activity appears to be an important process in aquaculture ponds, which decreases export of dissolved proteins to the surrounding environment and contributes significantly to the cycling of dissolved organic compounds into bacterial particulate material which can be tranferred to higher trophic levels by the microheterotrophic food chain. This study was restricted to a low level of aquaculture 
intensification. However, for intensive fish farming, stocking biomass and food supplied are frequently more than 10 time higher than in our semi-intensive pond. We cannot extrapolate our result to such situations, but we can assume that dissolved amino com- pound release and bacterial activity must have large effects on aquaculture production itself (e.g. oxygen consumption, food webs, etc.) and on eutrophication of the surrounding environment; however, these processes remain to be investigated.

\section{REFERENCES}

Admiraal W., G. M. J. Tubbing 1991. Extracellular enzyme activity associated with suspended matter in the River Rhine. Freshw. Biol. 26, 507-517.

Allan G. L., D. J. W. Moriarty, G. B. Maguire 1995. Effects of pond preparation and feeding rate on production of Penaeus monodon Fabricius, water quality, bacteria and benthos in model farming ponds. Aquaculture 130, 329-349.

Antia N. J., P. J. Harrison, L. Oliveira 1991. The role of dissolved organic nitrogen in phytoplankton nutrition, cell biology and ecology. Phycologia 30, 1-89.

Beveridge C. M. C., M. J. Phillips, R. M. Clarke 1991. A quantitative and qualitative assessment of wastes from aquatic animal production. In: Aquaculture and water quality. D.E. Brune, J.R. Tomasso eds. World Aquac. Soc., Baton Rouge, 506-533.

Briggs M. R. P., S. J. Funge-Smith 1994. A nutrient budget of some intensive marine shrimp pond in Thailand. Aquac. Fish. Manag. 25, 789-811.

Brooks S. P. J. 1992. A simple computer program with statistical test for the analysis of enzyme kinetics. Biotechniques 13, 906-911.

Chróst R. J. 1991. Environmental control of the synthesis and activity of aquatic microbial ectoenzymes. In: Microbial enzymes in aquatic environments. R.J. Chróst ed. Springer-Verlag, New York, 29-59.

Chróst R. J. 1992. Significance of bacterial ectoenzymes in aquatic environments. Hydrobiologia 243/244, 61-70.

Chróst R. J., U. Münster, H. Rai, D. Albrecht, P.K. Witzel, J. Overbeck 1989. Photosynthetic production and exoenzymatic degradation of organic matter in the euphotic zone of a eutrophic lake. J. Plankton Res. 11, 223-242.

Chróst R. J., H. Rai 1993 . Ectoenzyme activity and bacterial secondary production in nutrient-impoverished and nutrient-enriched freshwater mesocosms. Microb. Ecol. 25, $131-150$.

Chróst R. J., B. Riemman 1994. Storm-stimulated decomposition of organic matter in benthic/pelagic coastal mesocosms. Mar. Ecol. Prog. Ser. 108, 185-192.

Coffin R. B. 1989. Bacterial uptake of dissolved free and combined amino acids in estuarine waters. Limnol. Oceanogr. 34, 531-542.

Collinot C. 1994. Importance de l'azote organique dissous dans les marais maritimes atlantiques: relations avec la production et l'activité bactériennes. Mémoire DEA Université d'Aix-Marseille II, $48 \mathrm{p}$.

Delmas D., M. J. Garet 1995. SDS-preservation for deferred measurement of exoproteolytic kinetics in marine samples. J. Microbiol. Methods 22, 243-248.

Delmas D., M. G. Frikha, E. A. S. Linley 1990. Dissolved primary amine measurement by flow injection analysis with o-phthaldialdehyde: comparison with high-performance liquid chromatography. Mar. Chem. 29, 145-154.

Delmas D., M. G. Frikha, H. Reymond, E. A. S. Linley, Y. Collos 1992. Long term microbial community dynamics in a coastal marine pond. Mar. Microb. Food Webs 6 , $39-54$

Delmas D., C. Legrand, C. Bechemin, C. Collinot 1994. Exoproteolytic activity determined by flow injection analysis: its potential importance for bacterial growth in coastal marine ponds. Aquat. Living Resour. 7, 17-24.

Frikha M. G. 1989. Rôle des bactéries dans le réseau trophique et les processus de minéralisation d'un marais atlantique type claire à huîtres. Thèse $d r$. Univ. Bretagne Occidentale, Brest, $128 \mathrm{p}$.

Frikha M. G., E. A. S. Linley 1988/1989. Predation on bacterioplankton in oyster ponds of the Atlantic coast of France. Mar. Microb. Food Webs 3, 67-78.

Fuhrman J. A. 1987. Close coupling between release and uptake of dissolved free amino acids in sea water studied by an isotope dillution approach. Mar. Ecol. Prog. Ser. 37, 45-52.

Gardner W. S., J. A. Stephens 1978. Stability of terrestrially derived dissolved organic nitrogen in continental shelf surface waters. Mar. Chem. 6, 335-342.

Hobbie J. E., R. J. Daley, S. Jasper 1977. Use of nuclepore filters for counting bacteria by fluorescence microscopy. Appl. Environ. Microbiol. 33, 1225-1228.

Hollibaugh J. T., F. Azam 1983. Microbial degradation of dissolved proteins in seawater. Limnol. Oceanogr. 28, 1104-1116.

Hoppe H. G. 1983. Significance of exoenzymatic activities in the ecology of brackish water: measurements by means of methylumbelliferyl-substrates. Mar. Ecol. Prog. Ser. 11, 299-308.

Hoppe H. G. 1991. Microbial extracellular enzymes activity: a new key parameter in aquatic ecology. In: Microbial enzymes in aquatic environments. R.J. Chróst ed. Springer-Ver]ag, New York, 60-83.

Hoppe H. G. 1993. Use of fluorogenic model substrates for extracellular enzyme activity (EEA) measurement of bacteria. In: Handbook of methods in aquatic microbial ecology. P.F. Kemp, B.F. Sherr, E.B. Sherr, J.J. Cole eds. Lewis, Boca Raton, 423-431.

Hoppe H. G., H. Ducklow, B. Karrasch 1993. Evidence for dependency of bacterial growth on enzymatic hydrolysis of particulate organic matter in mesopelagic ocean. Mar. Ecol. Prog. Ser, 93, 277-283.

Hoppe H. G., S. J. Kim, K. Gocke 1988a. Microbial decomposition in aquatic environments: combined process of extracellular enzyme activity and substrate uptake. Appl. Environ. Microbiol. 54, 784-790.

Hoppe H. G., W. Schramm, P. Bacolod 1988b. Spatial and temporal distribution of pelagic microorganisms and their 
proteolytic activity over a partly destroyed coral reef. $M a r$. Ecol. Prog. Ser. 44, 95-102.

Hussenot J. 1992. Maîtriser la stimulation de la productivité naturclle permet de proposer une aquaculture marine scmi-intensive dans les marais de la côte atlantique française. Aqua Rev. 41, 31-33.

Jacobsen T. R., H. Ray 1991. Aminopeptidase activity in lakes of differing eutrophication. In: Microbial enzymes in aquatic environments. R. J. Chróst ed. Springer-Verlag, New York, 155-164.

Jobling M. 1993. Bioenergetic: feed intake and energy partitioning. In: Fish ecophysiology. J.C. Rankin, F.B. Jensen eds. Chapman et Hall, London, 1-44.

Jorgensen N. O .G. 1982. Heterotrophic assimilation and occurrence of dissolved free amino acids in a shallow estuary. Mar. Ecol. Prog. Ser. 8, 145-159.

Jorgensen N. O. G., N. Kroer, R.B. Coffin, X.H. Yang, C. Lee 1993. Dissolved free amino acids, combined amino acids, and DNA as sources of carbon and nitrogen to marine bacteria. Mar. Ecol. Prog. Ser. 98, 135-148.

Jumars P. A., D. L. Penry, J. A. Baross, M. J. Perry, B. W. Frost 1989. Closing the microbial loop: dissolved carbon pathway to heterotrophic bacteria from incomplete ingestion, digestion and absorption in animals. Deep-Sea Res. 36, 483-495.

Keil R. G., D. L. Kirchman 1991. Dissolved combined amino acids in marine waters as determined by vaporphase hydrolysis method. Mar. Chem. 33, 243-259.

Keil R. G., D. L. Kirchman 1993. Dissolved combined amino acids: chemical form and utilization by marine bacteria. Limnol. Oceanogr. 38, 1256-1270.

Krom M. D., A. Neory 1989. A total nutrient budget for an experimental intensive fishpond with circular moving seawater. Aquaculture 83, 345-358.

Krom M. D., J. Erez, C. B. Porter, S. Ellner 1989. Phytoplankton nutrient uptake dynamics in earthen marine fishponds under winter and summer conditions. Aquaculture 76, 237-253.

Krom M. D., S. Ellner, J. Van Rijn, A. Neori 1995. Nitrogen and phosphorus cycling and transformations in a prototype 'non-polluting' integrated mariculture system, Eilat, lsrael. Mar. Ecol. Prog. Ser. 118, 25-36.

Lampert W. 1978. Release of dissolved organic carbon by grazing zooplankton. Limnol. Oceanogr. 23, 831-834.

Lancelot C., G. Billen 1984. Activity of heterotrophic bacteria and its coupling to primary production during the spring bloom in the southern bight of the North Sea. Limnol. Oceanogr. 29, 721-730.

Lee C., S. G. Wakeham 1992. Organic matter in the water column: future research challenges. Mar. Chem. 39, 95 118.

Legrand C. 1993. Production primaire et bactérienne en marais maritimes: excrétion organique algale et utilisation par les bactéries. Thèse dr. Univ. Paul Sabatier, Toulouse, $189 \mathrm{p}$.
MacLcan M. H., K. J. Ang, J.H. Brown, J. C. Fry 1994. Aquatic and benthic responses to feed and fertiliser application in trials with the freshwater prawn, Macrobrachium rosenbergii (de Man). Aquaculture 120, 81-93.

Manaud F., J. M. Deslous-Paoli, P. Pichot, C. Juge, J. Hussenot, V. Buchet, A. Bodoit, P. Le Mao, J. L. Mauvais 1993. Aquaculture en marais et lagune ( $2^{\mathrm{e}}$ partie). Equinoxe 42 , 10-26.

Middelboe M., N. H. Borch, D.L. Kirchman 1995. Bacterial utilisation of dissolved free amino acids, dissolved combined amino acids and ammonium in the Delaware Bay estuary: effects of carbon and nitrogen limitation. Mar. Ecol. Prog. Ser. 128, 109-120.

Mopper K., P. Lindroth 1982. Diel and depth variations in dissolved free amino acids and ammonium in the Baltic Sea determined by shipboard analysis. Limnol. Oceanogr. 27, 336-347.

Moriarty D. J. W. 1986. Bacterial productivity in ponds used for culture of penaeid prawns. Microb. Ecol. 12, 259-269.

Moriarty D. J. W., R. S. V. Pullin 1987. Detritus and microbial ecology in aquaculture. ICLARM Conf. Proc. 14, Int. Center for Living Aquatic Resources Management, Manila, Philippines, $420 \mathrm{p}$.

Münster U., R. J. Chróst 1990. Origin, composition, and microbial utilization of dissolved organic matter. In: Aquatic microbial ecology. Biochemical and molecular approaches. J. Overbeck, R. J. Chróst eds. Springer-Verlag, New York, 8-46.

Payne J.W. 1980. Microorganisms and nitrogen sources. Wiley, New York, 870 p.

Rath J., C. Schiller, G. J. Herndl 1993. Ectoenzymatic activity and bacterial dynamics along a throphic gradient in the Caribbean Sea. Mar. Ecol. Prog. Ser. 102, 89-96.

Robert J. M., S. Y. Maestrini, M. Héral, Y. Zanette 1982. Production des micro-algues des claires ostréicoles en relation avec l'azote organique dissous excrété par les huîtres. Oceanol. Acta, Actes Symposium international sur les lagunes côtières, SCOR/JABO/UNESCO, Bordeaux, 389-395.

Rosenstock B., M. Simon 1993. Use of dissolved combined and free amino acids by planktonic bacteria in lake Constance. Limnol. Oceanogr. 38, 1521-1531.

Rosso A. L., F. Azam 1987. Proteolytic activity in coastal oceanic waters: depth distribution and relationship to bacterial populations. Mar. Ecol. Prog. Ser. 41, 231-240.

Sanders R. W., D. A. Caron, U. G. Berninger 1992. Relationships between bacteria and heterotrophic nanoplankton in marine and fresh waters: an inter-ecosystem comparison. Mar. Ecol. Prog. Ser. 86, 1-14.

Sharp J. H. 1983. The distribution of inorganic and dissolved and particulate organic nitrogen in the sea. $I n$ : Nitrogen in the marine environment. E.J. Carpenter, D.G. Capone eds. Academic Press, New York, 1-35.

Wright R. T., J. E. Hobbie 1966. Use of glucose and acetate by bacteria and algae in aquatic ecosystems. Ecology 47 , 447-464. 